\title{
A praeeclampsia pszichoszociális vonatkozásai
}

\author{
Szita Bernadett ${ }^{1}$ - Baji Ildikó dr. ${ }^{2}$ - Rigó János Jr. dr. ${ }^{1,3}$ \\ Semmelweis Egyetem, 'Általános Orvostudományi Kar, I. Szülészeti és Nőgyógyászati Klinika, \\ ${ }^{2}$ Egészségtudományi Kar, Családgondozási és Módszertani Tanszék, ${ }^{3}$ Szülészeti és Nőgyógyászati Klinikai \\ Ismeretek Tanszék, Budapest
}

\begin{abstract}
A praeeclampsia kialakulásához egyes esetekben pszichés faktorok is hozzájárulhatnak neuroendokrin és immunológiai mechanizmusok közvetítése révén, amelyek közül kiemelhető a hypothalamus-hypophysis-mellékvesekéreg tengely aktivitásának fokozódása és a proinflammatorikus citokinek szérumszintjének emelkedése. A praeeclampsia egyes pszichés zavarok előfordulását is megnöveli, a hosszan tartó hospitalizáció, a kontrollvesztés érzése, a koraszülés vagy a magzat egészségkárosodása következtében. Emellett a kórkép tartósan fennálló neurokognitív panaszokat okozhat, amelyek szintén negatívan befolyásolhatják az életminőséget. Tekintettel arra, hogy az anya rossz mentális állapota a terhesség kimenetelét és a magzat fejlődését egyaránt károsan befolyásolhatja, a praeeclampsiás nők számára a pszichológiai segítségnyújtás előnyös lehet. Orv. Hetil., 2015, 156(50), 2028-2034.
\end{abstract}

Kulcsszavak: praeeclampsia, terhesség, depresszió, hypothalamus-hypophysis-mellékvesekéreg tengely, pszichoterápia

\section{Psychosocial aspects of preeclampsia}

Distress conditions during pregnancy may contribute to the development of preeclampsia by altering functions of the neuroendocrine and immune systems, e.g. activation of the hypothalamic-pituitary-adrenal axis and increase in plasma proinflammatory cytokines. Preeclampsia may also precipitate mental health problems due to long-term hospitalization or unpredictable and uncontrollable events such as preterm labor and newborn complications. Besides, preeclampsia may induce persistent neurocognitive complaints with a negative impact on patients' quality of life. As growing evidence indicates that poor maternal mental health has an adverse effect on pregnancy outcome and fetal development, psychosocial interventions may be beneficial for women with preeclampsia.

Keywords: preeclampsia, pregnancy, depression, hypothalamic-pituitary-adrenal axis, psychotherapy

Szita, B., Baji, I., Rigó, J. Jr. [Psychosocial aspects of preeclampsia]. Orv. Hetil., 2015, 156(50), 2028-2034.

(Beérkezett: 2015. október 2.; elfogadva: 2015. október 29.)

\section{Rövidítések}

11 $\beta$-HSD2 = 11-béta-hidroxiszteroid-dehidrogenáz-2 izoenzim; ACTH = adrenokortikotrop hormon; CRH = corticotropin releasing hormon; EMDR = eye movement desensitization and reprocessing; HPA = hypothalamus-hypophysis-mellékvesekéreg tengely; PPD = postpartum depresszió; PTSD = poszttraumás stressz zavar; SNRI = (selective serotonin-norepinephrine reuptake inhibitor) szelektív szerotonin-noradrenalin visszavételgátló; SSRI = (selective serotonin reuptake inhibitor) szelektív szerotoninvisszavétel-gátló
A praeeclampsia a terhességek 5-8\%-ában fellépő súlyos szövődmény, amely hypertoniában, vizeletfehérje-ürítésben nyilvánul meg. Jellemzően a terhesség második vagy harmadik trimeszterében jelentkezik, és az anyai és magzati mortalitás és morbiditás egyik vezető oka világszerte. A kórkép patogenezise nem teljesen tisztázott. A praeeclampsia kialakulásában a placentáció zavara fontos szerepet játszik a terhesség korai szakaszában [1]. A rossz vérellátású, ezáltal hypoxiás placenta olyan faktorokat 
termel, amelyek endothelkárosodást okoznak az anyai vérkeringésben, aminek következtében érösszehúzódás, vérlemezke-aggregáció és a vascularis permeabilitás fokozódása jön létre [2]. Az anya vérkeringésében az oxidatív stressz fokozza a lipidperoxidációt, amely hozzájárul az endotheldiszfunkció kialakulásához [3]. Szintén megfigyelhető a szimpatikus idegrendszer hiperaktivitása. A megnövekedett szimpatikus aktivitás érösszehúzódást okozhat, amely a praeeclampsiában megfigyelhető patofiziológiás eltérés egyik kulcstényezője lehet [4]. Jelenlegi ismereteink tükrében feltételezhető, hogy egyes esetekben az anyai stressz is hozzájárul a praeeclampsia kialakulásához [5].

\section{A pszichés tényezők lehetséges szerepe a praeeclampsia patogenezisében}

A terhességre és a gyermekágyas időszakra a szérum nemihormon-szintek nagyfokú ingadozása jellemző, amely hatással lehet a várandós nők mentális állapotára, és a pszichés zavarok megnövekedett kockázatával jár együtt [6]. A depresszió, szorongás és egyéb pszichiátriai kórképek a terhesség alatt fontos rizikótényezői a vetélésnek, koraszülésnek és az alacsony születési súlynak [7]. Tanulmányok szerint a terhes nők 10\%-a felel meg a klinikai depresszió kritériumainak, 18\%-uknál pedig depresszív tünetek vannak jelen [8]. A pszichés stressz neuroendokrin és immunológiai mechanizmusokon keresztül gyakorolhat hatást a terhes nők és magzatuk egészségi állapotára [5].

\section{Pszicho-neuro-endokrinológiai összefüggések}

A krónikus stresszt, a szorongást és a hangulatzavarokat - többek között a major depressziót - gyakran hozzák összefüggésbe a hypothalamus-hypophysis-mellékvesekéreg (HPA) tengely szabályozásának zavarával. A pszichés stressz a HPA-tengely aktivitását fokozza, amely a hypothalamusban a corticotropin releasing hormon (CRH), a hypophysis elülső lebenyében az adrenokortikotropin (ACTH), végül a mellékvesekéregben termelődő glükokortikoidok, elsősorban a kortizol fokozott kiválasztásához vezet [9].

A glükokortikoidok fokozott termelődésének kedvezőtlen hatásai ismertek várandósság alatt. Már korábban igazolták, hogy praeeclampsiás terhességben a koraszülés összefügg a placenta magasabb kortizoltartalmával, köszönhetően a 11-béta-hidroxiszteroid-dehidrogenáz-2 (11ß-HSD2) izoenzim csökkent aktivitásának, amely a kortizolt kortizonná alakítja [10]. A nagyobb mértékú glükokortikoidtermelés, valamint a megváltozott kortizolmetabolizmus által kiváltott inzulinrezisztencia hozzájárulhat a magas vérnyomás és az endothelkárosodás kialakulásához is, amelyek praeeclampsiában megfigyelhetők [5]. A magas glükokortikoidaktivitás kapcsán megemlítendő, hogy hatására a 11ß-HSD2 izoenzim ál- tal kialakított placentáris barrier kevésbé hatékonyan kontrollálja és limitálja a magzat anyai kortizolhormonnal szembeni expozícióját, ami a magzat méhen belüli fejlődése mellett a magzati HPA-tengely múködését is kedvezőtlenül befolyásolja [11].

$\mathrm{Az}$ anya vérkeringésében lévő stresszhormonok - a kortizol, adrenalin és noradrenalin - megnövekedett szérumszintje további mechanizmusokon keresztül játszhat szerepet a praeeclampsia patogenezisében. Egyrészt fokozzák az oxidatív stresszt a vérkeringésben, hozzájárulva a lipidperoxidációhoz, amely endotheldiszfunkcióhoz vezet. Patkányokon végzett kísérletben igazolták, hogy lipidperoxidációt lehet kiváltani a vázizomzatban glükokortikoszteroidok adása után [12]. Másrészt a stresszhormonok csökkenthetik az uteroplacentáris vérkeringést a terhesség későbbi szakaszában is. Vemhes juhokon végzett vizsgálatban noradrenalin intravénás adása csökkentette az uteroplacentáris véráramlást a vemhesség késői fázisában [13].

Teixeria és mtsai kutatásában azoknál a terhes nóknél, akik kérdőíves felmérés alapján fokozott szorongással voltak jellemezhetők, magasabb arteria uterina rezisztenciaindex-értékeket találtak, összehasonlítva a kevésbé szorongó társaikkal, ami a distressz hatására bekövetkező vascularis rezisztencia növekedésére enged következtetni az uteroplacentáris vérkeringésben [14].

Mivel a krónikus stressz, a szorongás és a depresszió a cardiovascularis megbetegedések független kockázati tényezői, ugyancsak a pszichés faktorok szerepét támogatja az a tény is, hogy a praeeclampsia és a cardiovascularis megbetegedések patofiziológiájában olyan hasonlóságok fedezhetők fel, mint a szimpatikus idegrendszer fokozott aktivitása, az endothelkárosodás, a vasoconstrictio és a szerotonin mediálta thrombocytaaktiváció és -aggregáció [15].

\section{Pszicho-neuro-immunológiai hatások}

Egyes vizsgálatok szerint a pszichés stressz az immunrendszerre gyakorolt hatásán keresztül is hozzájárulhat a praeeclampsia kialakulásához. A krónikus stresszt és a szorongásos, illetve depresszív állapotokat régóta összefüggésbe hozzák a proinflammatorikus citokinek (IL-1, IL-6, TNF- $\alpha$ ) szérumszintjének emelkedésével [16]. A krónikus stressz hatására aktiválódó HPA-tengely és az immunrendszer között kétirányú regulációs folyamat megy végbe. A proinflammatorikus citokinek (IL-1 $\beta$, IL6 , TNF- $\alpha$ ) fokozzák a HPA-tengely múködését, amely megnövekedett kortizoltermelődéshez vezet [17]. A kortizol negatív visszacsatolás révén, az antiinflammatorikus citokin (IL-1RA, sTNF-RII) termelés emelésével ugyanakkor a proinflammatorikus citokinképződést és ezáltal a gyulladásos válaszok mértékét is csökkenti [18]. Krónikus stressz vagy depresszió során viszont a kortizol kevésbé hatékonyan szabályozza az inflammatorikus citokinek termelődését, az immunsejtekben lévő glükokortikoidreceptorok csökkent válaszkészsége miatt [18]. 
E mechanizmusnak köszönhetően az inflammatorikus citokinek magasabb, az antiinflammatorikus citokinek alacsonyabb szérumszintje jellemző hosszabb ideig fennálló pszichés megterhelés esetén [19].

Várandósság alatt az immunrendszer szuppressziója, illetve az inflammatorikus immunválaszoktól az antiinflammatorikus válaszok irányába való eltolódás figyelhetô meg. Ez a sajátosság biztosítja a magzat egészséges fejlődését a kedvező immunológiai környezet kialakítása révén [20]. A praeeclampsiával szövődött terhességekben ugyanakkor a proinflammatorikus citokinek (IL-1 $\beta$, IL-6, IL-8, TNF- $\alpha$ ) magasabb szérumszintje figyelhető meg, amely az antiinflammatorikus citokinek csökkenésével is együtt jár [21, 22]. A proinflammatorikus citokinek fokozott termelődése valószínú, hogy kulcsfontosságú szerepet tölt be a praeeclampsia patofiziológiájában [23]. A vérkeringésben megnövekedett IL-6-szint hozzájárulhat az endothelsejtek károsodásához és a vascularis diszfunkció kialakulásához [24]. Továbbá az emelkedett IL-6-szint lokálisan a deciduális makrofágok számát növeli, ami gátolhatja az extravillosus trofoblasztinváziót és nagy mennyiségű trofoblasztsejt-pusztuláshoz vezethet, ezáltal károsítva az uteroplacentáris keringést [24]. Újabb kutatási eredmények pedig arra hívják fel a figyelmet, hogy a proinflammatorikus citokinek a hypertonia, a vizeletfehérje-ürítés és az ödéma kialakulásában is szerepet játszhatnak [23]. Ezek az immunológiai sajátosságok a praeeclampsia kedvezőtlen kimenetelét is, így a koraszülés bekövetkeztét is előidézhetik [25].

A pszichés stressz immunmoduláló hatását igazolja Coussons-Read és mtsai vizsgálata, amelyben a terhesség alatt átélt nagyfokú stressz és alacsony társas támogatottság a proinflammatorikus citokinek magasabb szérumkoncentrációjával járt együtt [26]. Giurgescu és mtsai kutatásukban az előbbiekkel összhangban lévő eredményeket kaptak: a magasabb társas támogatottságról beszámoló nók esetében a proinflammatorikus citokinek (IL-2, IL-5, IL-6) alacsonyabb szérumszintje volt kimutatható [27].

\section{A pszichés faktorok vizsgálata praeeclampsiában}

$\mathrm{Az}$ eddigi viszonylag kevés számú kutatás támogatja a pszichoszociális változók szerepét a praeeclampsia patogenezisében. Egy 623 primipara bevonásával készült kutatás eredményei szerint a várandósság alatti depresszió 2,5-szeres, a szorongás 3,2-szeres kockázatot jelent a praeeclampsia kialakulására nézve [28]. Qiu és mtsai vizsgálati eredményei szerint a terhességük alatt mérsékelt depressziós tüneteket mutató nőknek 2,3-szer, a súlyosabb tüneteket mutatóknak 3,2-szer nagyobb kockázatuk volt a praeeclampsia kialakulására [29]. Kharaghani és mtsai kutatásában a középsúlyos, illetve súlyos depresszióval diagnosztizált nők 2,5-szer nagyobb valószínûséggel lettek praeeclampsiásak várandósságuk során [30]. Továbbá, az anya kórtörténetében szereplő korábbi pszichiátriai zavarok - különös tekintettel a depresszi- ós és szorongásos kórképekre - szintén megnövelhetik a praeeclampsia kialakulásának esélyét [31].

Emellett a betegség kialakulása közvetlenül összefügg olyan egyes, pszichés zavarokra jellemző egészségkárosító magatartásokkal, mint a terhesség előtti és alatti dohányzás, a nem megfelelő táplálkozás és vitaminbevitel, valamint a fizikai inaktivitás [29]. Haelterman és mtsai vizsgálatában azoknál a nőknél, akik fokozottabb fizikai vagy pszichés munkahelyi stressznek voltak kitéve, nagyobb eséllyel alakult ki praeeclampsia [32]. Ugyanakkor két másik kutatásban, amelyekben praeeclampsiás, gesztációs és krónikus hypertoniával diagnosztizált nők pszichés státuszát hasonlították össze, a klinikai depresszió és szorongás nagyobb arányú előfordulása csak a krónikus hypertoniás csoportban volt kimutatható, a praeeclampsiás nők körében csak koraszüléssel végződő terhesség esetén találtak hasonló összefüggést $[33,34]$.

$H u$ és mtsai metaanalízisében 12 tanulmány eredményeinek elemzése során a terhesség alatti depresszió és praeeclampsia előfordulása között mérsékelt erősségü, de szignifikáns korrelációt találtak; a súlyosabb depreszsziós tüneteket mutató nők körében pedig már közel kétszer nagyobb gyakorisággal jelent meg a kórkép [35]. Az összefüggés a terhesség előtti BMI - ami a praeeclampsia ismert rizikófaktora - kontrollálását követően is fennmaradt.

Végül fontos megjegyezni, hogy bár több kutatás igazolta a pszichés problémák nagyobb arányú előfordulását patológiás terhességekben [5, 7], az ok-okozati öszszefüggés nem tisztázott. A terhesség alatt észlelt stressz, illetve patológiás személyiségjegyek valószínúleg megnövelik a terhességi szövődmények kockázatát. Ugyanakkor a várandósság során jelentkező kóros állapotok is szorongást és depressziós tüneteket válthatnak ki. Különösen igaz ez a praeeclampsiás nőkre, ahol a betegség kialakulása számos esetben hirtelen és váratlanul következik be, és gyorsan kell alkalmazkodni azokhoz a változásokhoz, amelyek az anya állapotromlásának veszélyével járnak. A hosszabb kórházi tartózkodás, a beteg saját testi tüneteire fordított fokozott figyelme, a koraszülés veszélye, a magzat egészsége miatti aggodalom, és öszszességében a terhesség kimenetele felett érzett kontrollvesztés mind olyan tényezők, amelyek önmagukban is megnövelhetik az anya szorongását, valamint hangulati problémákat idézhetnek elő [36].

\section{A praeeclampsia hatása a kognitív müködésre}

A praeeclampsia olyan, több szervrendszert érintő betegség, amely az akut, súlyos neurológiai szövődmények (például: ischaemiás és haemorrhagiás agyvérzés, corticalis vakság) mellett lassabban kialakuló, de tartósan fennálló neurokognitív panaszokat is okozhat [37, 38]. Annak ellenére, hogy a tünetek nem feltétlenül súlyosak, kihathatnak a mindennapi életvitelre és negatívan befolyásolhatják az életminőséget [39]. A panaszok mögött 
álló patomechanizmusok egyelőre tisztázatlanok, mint ahogy az sem egyértelmú, hogy objektíven mérhető kognitív zavarról van-e szó vagy az átélt nehézségek miatt bekövetkező pszichológiai problémák okoznak-e szubjektíven észlelt mentális deficitet. Ennek megfelelően, egyes szerzők cerebralis károsodást, mások az elhúzódó poszttraumás vagy depressziós-szorongásos tüneteket teszik felelőssé a kognitív panaszok kialakulásáért és fennmaradásáért $[38,40,41]$.

Annak ellenére, hogy számos kutatás foglalkozott a praeeclampsia akut neurológiai következményeivel, a kognitív funkciók érintettségét illetően kevés számú vizsgálat született.

Rana és mtsai nem találtak különbséget a praeeclampsiás és egészséges kontrollcsoport között a kognitív teljesítményt standardizált neuropszichológiai tesztekkel mérve a szülést követő második napon [42]. Brussé és mtsai a szülést követő 3-8. hónapban elvégzett vizsgálatukban a praeeclampsiás csoportban az auditoros-verbális memória terén találtak gyengébb teljesítményt, míg az általános intelligencia, a végrehajtó funkciók, valamint a nyelvi készségek esetében nem volt kimutatható különbség az egészséges kontrollcsoporthoz képest [37]. Baecke és mtsai vizsgálatukban nem találtak objektíven mérhető kognitív képességromlást a praeeclampsiás csoportban az egészséges kontrollokhoz viszonyítva, ugyanakkor a pszichiátriai zavarral is küzdő személyek szignifikánsan rosszabbul teljesítettek a neuropszichológiai teszteken [40]. Sajnos a szerzők nem közöltek információt arról, hogy a pszichiátriai érintettségú, de szövődménymentes terhességű nők eredményei eltértek-e az utóbbi csoportétól.

Postma és mtsai 150 fös utánkövetéses vizsgálatukban a korábban eclampsiás, praeeclampsiás és szövődménymentes várandósságú nők kognitív teljesítményét mérték fel, átlagosan 7 évvel a praeeclampsiás terhességet követően [38]. A kutatásban a főbb kognitív képességek (vizuális percepció, motoros funkciók, figyelem, munkamemória, hosszú távú memória, végrehajtó funkciók) vizsgálata mellett a szubjektív funkcióromlást (például: észlelt memória-, figyelemzavar), valamint a szorongás és depresszív hangulat meglétét is felmérték önkitöltős kérdőívekkel. Az eredmények nem jeleztek objektív károsodást az eclampsiás/praeeclampsiás csoportban az egészséges kontrollokhoz viszonyítva egyik kognitív képesség terén sem. Ugyanakkor az előbbi két csoportban szignifikánsan nagyobb arányban jeleztek szubjektív - a mindennapi életben tapasztalt - kognitív funkcióromlást, valamint magasabb pontszámot értek el a depressziót, szorongást vizsgáló kérdőíveken, ami magyarázatot adhat a kognitív károsodás objektív és szubjektív mérési eredményei közti különbségre.

A szorongás és a depresszió számos mechanizmuson keresztül ronthatja a kognitív teljesítményt a mindennapi élet során; például kiszolgáltatottabbá teszi az egyént a stresszkeltő életesemények hatásaival szemben, kihathat a figyelmi funkciók múködésére, amely mind a memória, mind a problémamegoldás múködését ronthatja. A szerzők felvetik annak a lehetőségét is, hogy az eclampsiás és praeeclampsiás csoportra már a praeeclampsiás terhesség előtt fokozott szorongás és rosszabb hangulat volt jellemző, amely hozzájárulhatott a kóros terhességi állapot kialakulásához [38]. Ugyanakkor, hosszabb távú utánkövetéses vizsgálatokban azoknál a nőknél, akiknek a kórelőzményében praeeclampsiával vagy eclampsiával szövődött terhesség szerepelt, nagyobb arányban találtak cerebralis fehérállományi laesiót, mint az egészséges várandósoknál [41, 43].

Újabb neurológiai kutatásokban kimutatták, hogy a szubjektív memóriapanaszok gyakran járnak együtt fehérállományi laesiókkal, amelyek a vizsgálat időpontjában még nem, évekkel később viszont már objektíven mérhető kognitív zavarban nyilvánulnak meg [44]. Emiatt további kutatások szükségesek a praeeclampsiás terhességet követő szubjektív kognitív zavarok hátterében esetlegesen meghúzódó strukturális eltérések képalkotó vizsgálatokkal történő feltárására.

\section{A praeeclampsia hatása a mentális egészségre}

Azok a nők, akiknél várandósságuk során valamilyen kóros terhességi állapot (például: fenyegető vetélés, praeeclampsia, gestatiós diabetes) alakul ki, a szülést követően nagyobb kockázatnak vannak kitéve a mentális zavarok kialakulását illetően [45]. A praeeclampsia pszichés következményeivel kapcsolatban leggyakrabban vizsgált kórképek a poszttraumás stressz zavar (PTSD), valamint a depressziós és szorongásos tünetegyüttesek. A praeeclampsia jelentős pszichés megterhelést jelenthet az érintett nók számára, mivel gyakran váratlanul következik be, hosszan tartó hospitalizációt igényel és aggodalmakra ad okot a terhesség kimenetelével, az anya és a magzat egészségének alakulásával kapcsolatban [46]. Az esetek egy részében a félelmek beigazolódnak, és a magzat korábban jön a világra, gyakran igen kis születési súllyal, rossz általános állapotban, amelynek következtében maradandó károsodásokat szenvedhet.

Kevés kutatási adat áll rendelkezésre a praeeclampsia és a postpartum depresszió (PPD) kapcsolatáról. A terhességi és születési szövődmények általában összefüggést mutatnak a PPD kialakulásának gyakoriságával [47]. Így a praeeclampsia közvetetten - a perinatalis szövődmények kialakulása révén - is megnövelheti a PPD kialakulásának esélyét. A praeeclampsia és a PPD kapcsolatát vizsgáló kutatások egy részében pozitív korrelációt találtak a két kórkép előfordulása között $[48,49,50]$. Engelhard és mtsai kutatásában a depresszió szignifikánsan gyakoribb előfordulása volt kimutatható a terminusban szülő praeeclampsiás nők körében a szövődménymentes terhességű nőkhöz viszonyítva, koraszülés esetén viszont már nem volt eltérés a két csoportban [46]. Baecke és mtsai ugyanakkor a depresszió súlyosságát vizsgálva szignifikáns különbséget találtak a koraszülött gyermeket vi- 
lágra hozó praeeclampsiás és egészséges nők között, de nem tudtak kimutatni eltérést a terminusban szülő nők esetében [40]. Két másik kutatócsoport pedig semmilyen összefüggést nem talált a praeeclampsia és a PPD előfordulása között $[51,52]$.

Összegezve a kutatási eredményeket, a praeeclampsia fokozott kockázatot jelenthet a PPD kialakulásának tekintetében, ugyanakkor nem dönthetô el egyértelmúen, hogy a magzat egészségi állapotán kívül egyéb tényezők is befolyásolják-e a pszichés zavar kialakulását. A postpartum időszakban jelentkező szorongást vizsgáló kutatások viszont nem tudták egyértelmúen igazolni a szorongás gyakoribb előfordulását a praeeclampsiával szövődött terhességek esetében [37, 40].

A PTSD kialakulásának kockázata fokozott praeeclampsiás nők körében, mivel a betegség jellegéből adódóan gyakran kerülnek olyan súlyos állapotba (például: HELLP-szindróma), amely során testi épségük, akár az életben maradásuk is veszélyben van; az átélt események intenzív félelmet válthatnak ki, a helyzetük feletti kontroll képessége pedig megszünik [46]. A PTSD előfordulását vizsgálva Delahaije és mtsai tanulmányukban a PTSD szignifikánsan nagyobb előfordulását találták a praeeclampsiás terhességü nők körében, és ellentétben a PPD-vel, a szülés terminusa nem befolyásolta a kórkép kialakulásának gyakoriságát [45]. Tehát a praeeclampsia mentális egészségre gyakorolt hatásáról elmondható, hogy mind a PPD, mind a PTSD megnövekedett kockázatával jár együtt, míg azonban PPD kialakulásában a koraszülés feltehetően kulcstényező, addig a PTSD-s tünetek a szülés kimenetelétől függetlenül is nagyobb arányban jelentkeznek a praeeclampsiás nők körében.

\section{A pszichológiai intervenciók szerepe}

A pszichoszociális tényezők szerepe a praeeclampsia kialakulásában egyelőre tisztázatlan, ugyanakkor az állapot mind a terhesség során, mind a post partum időszakban rosszabb életminőséggel (szorongás, hangulatzavarok, valamint a PTSD kialakulásának nagyobb kockázata) jár együtt $[45,48]$. A fentiek miatt - függetlenül attól, hogy a pszichés problémák hozzájárulnak-e a praeeclampsia patogeneziséhez vagy csak következményei annak - a mentálhigiénés intervencióknak helye van a kórkép kezelésében. A pszichológiai segítségnyújtás szükségességére utal az a tény, hogy a praeeclampsiás várandósságok jelentős része végződik koraszüléssel, amely további, tartós pszichés megterhelést jelent.

A pszichoterápiás beavatkozások jelentősége azért is kiemelkedő, mert a terhesség alatti pszichotróp medikáció a magzati fejlődésre gyakorolt hatása miatt sok esetben kerülendő, illetve csak megfelelő körültekintéssel alkalmazható. Ezenkívül a klinikumban leggyakrabban használt SSRI (selective serotonin reuptake inhibitor) és SNRI (selective serotonin-norepinephrine reuptake inhibitor) készítmények növelhetik a hypertonia és praeeclampsia kialakulásának kockázatát [53]. Avalos és mtsai vizsgálatában a pszichoterápiás kezelésben részesülő depressziós nók körében nem emelkedett a praeeclampsia kialakulásának kockázata, szemben a kezeletlen és az antidepresszív gyógyszert (különös tekintettel az SSRIkészítményekre) szedő depressziós nőkkel [54]. Az antidepresszív szer használata elsősorban a második trimeszterben társult a praeeclampsia kialakulásának megnövekedett esélyével. A fentiek miatt a pszichológiai beavatkozások előnyt élvezhetnek a farmakoterápiával szemben azokban az esetekben, ahol nagyobb a terhességi szövődmény rizikója, és a mentális probléma jellege, súlyossága nem indokolja feltétlenül a gyógyszeres kezelés alkalmazását [53].

Poel és mtsai 24 praeeclampsiás, illetve HELLP-szindrómás nő utánkövetéses vizsgálatában a leggyakrabban előforduló pszichés panaszokat (1. táblázat) mérték fel [55]. Az intervenciós lehetőségek közül pszichoedukációt a betegség jobb megértése, EMDR- (eye movement desensitization and reprocessing) terápiát a PTSD-s tünetek csökkentése, kognitív-viselkedéses technikákat pedig a hatékonyabb megküzdési stratégiák kialakítása és a depressziós tünetek kezelése céljából alkalmaztak. A szerzők tanulmányukban kiemelték a probléma időben történő felismerésének fontosságát, ami lényegesen lerö-

1. táblázat | Praeeclampsiával összefüggésben kialakuló pszichés panaszok*

\begin{tabular}{|c|c|}
\hline Pszichés tünetek & $\begin{array}{l}\text { Vizsgált személyek } \\
\qquad(\mathrm{n}=24)\end{array}$ \\
\hline \multicolumn{2}{|l|}{ Általános közérzet } \\
\hline Fáradtság & 19 \\
\hline Koncentrációs zavarok & 16 \\
\hline Memóriaproblémák & 11 \\
\hline Fejfájás & 5 \\
\hline Alvászavar & 4 \\
\hline Fülzúgás & 2 \\
\hline Hányinger & 1 \\
\hline Látászavar & 1 \\
\hline \multicolumn{2}{|l|}{ PTSD-hez kapcsolódó } \\
\hline Megnövekedett arousal & 15 \\
\hline Szorongás, feszültségérzés & 10 \\
\hline Trauma újbóli átélése & 9 \\
\hline \multicolumn{2}{|l|}{ Egyéb } \\
\hline Munkahelyi alkalmazkodási zavarok & 9 \\
\hline Depressziós tünetek & 6 \\
\hline Kontrollvesztés érzése & 3 \\
\hline Bûntudat & 3 \\
\hline Sérült testkép & 3 \\
\hline Nehézség a betegség megértésében & 2 \\
\hline Gyászfolyamat a gyermek halála következtében & 2 \\
\hline
\end{tabular}

*Forrás: Poel, Ү. H., et al., J. Psychosom. Obstet. Gynaecol., 2009 [55] - a szerző engedélyével. 
vidíti a szükséges pszichoterápiás beavatkozások időtartamát.

Jelenleg nem állnak rendelkezésre szisztematikus kutatási adatok arra vonatkozóan, hogy a terhesség alatt végzett pszichológiai intervenciók hogyan befolyásolják a praeeclampsia lefolyását, kimenetelét. A jövőben értékes kutatási terület lehet annak vizsgálata, hogy a mentálhigiénés beavatkozások milyen hatást gyakorolnak a praeeclampsiás nők pszichés és szomatikus állapotára, mivel a várandósság során diagnosztizált mentális zavarok esetében a pszichoterápiás beavatkozások nemcsak a pszichés, hanem a terhességi szövődmények tekintetében is pozitív következményekkel járhatnak [56].

\section{Következtetések}

A praeeclampsia fokozott kockázatot jelent a mentális zavarok kialakulását illetően az antenatalis és postnatalis időszakban. Irodalmi adatok alapján feltételezhető, hogy a kóros pszichés állapotok nemcsak a praeeclampsia következményeként léphetnek fel, hanem egyes esetekben annak kialakulásában, lefolyásában is szerepük lehet.

A praeeclampsiás nők körében tapasztalt enyhe és jellemzően átmeneti kognitív képességromlás szintén negatív hatást gyakorol a nők életminőségére, bár a tünetekkel kapcsolatban nem dönthető el egyértelmüen, hogy azok neurológiai etiológiájú zavarnak vagy a komorbid pszichés kórképek következményének tulajdoníthatók-e.

A pszichoszociális faktorok szerepének megítélésében nehézséget jelent, hogy a kutatások többsége kis mintaelemszámú, és az alkalmazott mérőeszközök, a mentális zavarok definiálása, valamint a vizsgálati elrendezés tekintetében egyaránt nagy heterogenitást mutatnak. Fentiek miatt több szisztematikus vizsgálatra lenne szükség a mentális zavarok szerepének pontosabb megértéséhez a praeeclampsiával összefüggésben.

A klinikai gyakorlatban - a pszichés zavarok nagyobb kockázata miatt - a praeeclampsiás nők pszichés státuszának fokozott monitorizálása, a depresszió, a szorongás szürése, és az időben megkezdett intervenciós beavatkozások az anya és a magzat egészsége szempontjából egyaránt kiemelt fontosságúak.

Anyagi támogatás: A közlemény megírása anyagi támogatásban nem részesült.

Szerzői munkamegosztás: Sz. B.: Témafelvetés, irodalomkutatás, a kézirat megszövegezése. B. I.: A kézirat szakmai értékelése, a szakirodalom kritikus értékelése. R. J.: A kézirat lektorálása, szakmai értékelése, a szakirodalom kritikus értékelése. A cikk végleges változatát valamennyi szerző elolvasta és jóváhagyta.

Érdekeltségek: A szerzőknek nincsenek érdekeltségeik.

\section{Irodalom}

[1] Roberts, J. M., Redman, C. W.: Pre-eclampsia: more than pregnancy-induced hypertension. Lancet, 1993, 341(8858), 14471451 .

[2] Roberts, J. M., Taylor, R. N., Musci, T. J., et al.: Preeclampsia: an endothelial cell disorder. Am. J. Obstet. Gynecol., 1989, 161(5), 1200-1204.

[3] Walsh, S. W.: Maternal-placental interactions of oxidative stress and antioxidants in preeclampsia. Semin. Reprod. Endocrinol., 1998, 16(1), 93-104.

[4] Schobel, H. P., Fischer, T., Heuszer, K., et al.: Preeclampsia - a state of sympathetic overactivity. N. Engl. J. Med., 1996, 335(20), 1480-1485.

[5] Vianna, P., Baner, M. E., Dornfeld, D., et al.: Distress conditions during pregnancy may lead to pre-eclampsia by increasing cortisol levels and altering lymphocyte sensitivity to glucocorticoids. Med. Hypotheses, 2011, 77(2), 188-191.

[6] Marcus, S. M.: Depression during pregnancy: rates, risks and consequences - Motherisk Update 2008. Can. J. Clin. Pharmacol., 2009, 16(1), el5-e22.

[7] Grote, N. K., Bridge, J. A., Gavin, A. R., et al.: A meta-analysis of depression during pregnancy and the risk of preterm birth, low birth weight, and intrauterine growth restriction. Arch. Gen. Psychiatry, 2010, 67(10), 1012-1024.

[8] Vesga-López, O., Blanco, C., Keyes, K., et al.: Psychiatric disorders in pregnant and postpartum women in the United States. Arch. Gen. Psychiatry, 2008, 65(7), 805-815.

[9] Dragoş, D., Tănăsescu, M. D.: The effect of stress on the defense systems. J. Med. Life, 2010, 3(1), 10-18.

[10] Aufdenblatten, M., Baumann, M., Raio, L., et al.: Prematurity is related to high placental cortisol in preeclampsia. Pediatr. Res., 2009, 65(2), 198-202.

[11] Reynolds, R. M.: Glucocorticoid excess and the developmental origins of disease: two decades of testing the hypothesis -2012 Curt Richter Award Winner. Psychoneuroendocrinology, 2013, $38(1), 1-11$.

[12] Ohtsuka, A., Ohtani, T., Horiguchi, H., et al.: Vitamin E reduces glucocorticoid-induced growth inhibition and lipid peroxidation in rats. J. Nutr. Sci. Vitaminol. (Tokyo), 1998, 44(2), 237-247.

[13] Rosenfeld, C. R., West, J.: Circulatory response to systemic infusion of norepinephrine in the pregnant ewe. Am. J. Obstet. Gynecol., 1977, 127(4), 376-383.

[14] Teixeira, J. M., Fisk, N. M., Glover, V.: Association between maternal anxiety in pregnancy and increased uterine artery resistance index: cohort based study. BMJ, 1999, 318(7177), 153157.

[15] Rodie, V. A., Freeman, D. J., Sattar, N., et al.: Pre-eclampsia and cardiovascular disease: metabolic syndrome of pregnancy? Atherosclerosis, 2004, 175(2), 189-202.

[16] Cohen, S., Doyle, W. J., Skoner, D. P.: Psychological stress, cytokine production, and severity of upper respiratory illness. Psychosom. Med., 1999, 61(2), 175-180.

[17] Kunz-Ebrecht, S. R., Mohamed-Ali, V., Feldman, P. J., et al.: Cortisol responses to mild psychological stress are inversely associated with proinflammatory cytokines. Brain Behav. Immunol., 2003, 17(5), 373-383.

[18] Elenkov, I. J., Chrousos, G. P.: Stress hormones, proinflammatory and antiinflammatory cytokines, and autoimmunity. Ann. N. Y. Acad. Sci., 2002, 966, 290-303.

[19] Coussons-Read, M. E., Okun, M. L., Nettles, C. D.: Psychosocial stress increases inflammatory markers and alters cytokine production across pregnancy. Brain Behav. Immunol., 2007, 2l(3), 343-350.

[20] Jonsson, Ү., Rubèr, M., Matthiesen, L., et al.: Cytokine mapping of sera from women with preeclampsia and normal pregnancies. J. Reprod. Immunol., 2006, 70(1-2), 83-91. 
[21] Szarka, A., Rigó, J. Jr., Lázár, L., et al.: Circulating cytokines, chemokines and adhesion molecules in normal pregnancy and preeclampsia determined by multiplex suspension array. BMC Immunol., 2010, 11, 59.

[22] Kalinderis, M., Papanikolaou, A., Kalinderi, K., et al.: Elevated serum levels of interleukin- 6 , interleukin- $1 \beta$ and human chorionic gonadotropin in pre-eclampsia. Am. J. Reprod. Immunol., $2011,66(6), 468-475$.

[23] Raghupathy, R.: Cytokines as key players in the pathophysiology of preeclampsia. Med. Princ. Pract., 2013, 22(Suppl. 1), 8-19.

[24] Lockwood, C. J., Yen, C. F., Basar, M., et al.: Preeclampsia-related inflammatory cytokines regulate interleukin- 6 expression in human decidual cells. Am. J. Pathol., 2008, 172(6), 1571-1579.

[25] Engel, S. A., Erichsen, H. C., Savitz, D. A., et al.: Risk of spontaneous preterm birth is associated with common proinflammatory cytokine polymorphisms. Epidemiology, 2005, 16(4), 469-477.

[26] Coussons-Read, M. E., Okun, M. L., Schmitt, M. P., et al.: Prenatal stress alters cytokine levels in a manner that may endanger human pregnancy. Psychosom. Med., 2005, 67(4), 625-631.

[27] Giurgescu, C., Sanguanklin, N., Engeland, C. G., et al.: Relationships among psychosocial factors, biomarkers, preeclampsia, and preterm birth in African American women: a pilot. Appl. Nurs. Res., 2015, 28(1), el-e6.

[28] Kurki, T., Hiilesmaa, V., Raitasalo, R., et al.: Depression and anxiety in early pregnancy and risk for preeclampsia. Obstet. Gynecol., 2000, 95(4), 487-490.

[29] Qiu, C., Sanchez, S. E., Lam, N., et al.: Associations of depression and depressive symptoms with preeclampsia: results from a Peruvian case-control study. BMC Womens Health, 2007, 7, 15 .

[30] Kharaghani, R., Geranmaye, M., Janani, L., et al.: Preeclampsia and depression: a case-control study in Tehran. Arch. Gynecol. Obstet., 2012, 286(1), 249-253.

[31] Qiu, C., Williams, M. A., Calderon-Margalit, R., et al.: Preeclampsia risk in relation to maternal mood and anxiety disorders diagnosed before or during early pregnancy. Am. J. Hypertens., 2009, 22(4), 397-402.

[32] Haelterman, E., Marcoux, S., Croteau, A., et al.: Populationbased study on occupational risk factors for preeclampsia and gestational hypertension. Scand. J. Work Environ. Health, 2007, 33(4), 304-317.

[33] Katon, W. J., Russo, J. E., Melville, J. L.: Depression in pregnancy is associated with preexisting but not pregnancy-induced hypertension. Gen. Hosp. Psychiatry, 2012, 34(1), 9-16.

[34] Thombre, M. K., Talge, N. M., Holzman, C.: Association between pre-pregnancy depression/anxiety symptoms and hypertensive disorders of pregnancy. J. Womens Health (Larchmt.), 2015, 24(3), 228-236.

[35] $H u, R ., L i, \Upsilon$., Zhang, Z., et al.: Antenatal depressive symptoms and the risk of preeclampsia or operative deliveries: a meta-analysis. PLoS ONE, 2015, 10(3), e0119018.

[36] Black, K. D.: Stress, symptoms, self-monitoring confidence, wellbeing, and social support in the progression of preeclampsia/ gestational hypertension. J. Obstet. Gynecol. Neonatal. Nurs., 2007, 36(5), 419-429.

[37] Brussé, I., Duvekot, J., Jongerling, J., et al.: Impaired maternal cognitive functioning after pregnancies complicated by severe pre-eclampsia: a pilot case-control study. Acta Obstet. Gynecol. Scand., 2008, 87(4), 408-412.

[38] Postma, I. R., Bouma, A., Ankersmit, I. F., et al.: Neurocognitive functioning following preeclampsia and eclampsia: a long-term follow-up study. Am. J. Obstet. Gynecol., 2014, 211(1), 37.el37.e9.

[39] Postma, I. R., Groen, H., Easterling, T. R., et al.: The brain study: Cognition, quality of life and social functioning following preec- lampsia; An observational study. Pregnancy Hypertens., 2013, $3(4), 227-234$

[40] Baecke, M., Spaanderman, M. E., van der Werf, S. P.: Cognitive function after pre-eclampsia: an explorative study. J. Psychosom. Obstet. Gynaecol., 2009, 30(1), 58-64.

[41] Aukes, A. M., de Groot, J. C., Aarnoudse, J. G., et al.: Brain lesions several years after eclampsia. Am. J. Obstet. Gynecol., 2009, 200(5), 504.el-504.e5.

[42] Rana, S., Lindheimer, M., Hibbard, J.: Neuropsychological performance in normal pregnancy and preeclampsia. Am. J. Obstet. Gynecol., 2006, 195(1), 186-191.

[43] Aukes, A. M., De Groot, J. C., Wiegman, M. J., et al.: Long-term cerebral imaging after pre-eclampsia. BJOG, 2012, 119(9), 1117-1122.

[44] Stewart, R., Godin, O., Crivello, F., et al.: Longitudinal neuroimaging correlates of subjective memory impairment: 4-year prospective community study. Br. J. Psychiatry, 2011, 198(3), 199205.

[45] Delahaije, D., Dirksen, C., Peeters, L., et al.: Mental health problems following preeclampsia or HELLP syndrome: Do we have a case? A systematic review. Pregnancy Hypertens., 2012, 2(3), 296.

[46] Engelhard, I. M., van Rij, M., Boullart, I., et al.: Posttraumatic stress disorder after pre-eclampsia: an exploratory study. Gen. Hosp. Psychiatry, 2002, 24(4), 260-264.

[47] Vliegen, N., Casalin, S., Luyten, P.: The course of postpartum depression: a review of longitudinal studies. Harv. Rev. Psychiatry, 2014, 22(1), 1-22.

[48] Blom, E. A., Jansen, P. W., Verhulst, F. C., et al.: Perinatal complications increase the risk of postpartum depression. The Generation R Study. BJOG, 2010, 117(11), 1390-1398.

[49] Rigó, J. Jr., Kecskeméti, A., Molvarec, A., et al.: Postpartum depression and anxiety in hypertensive disorders of pregnancy. Pregnancy Hypertens., 2015, 5(1), 117-118. [Abstract]

[50] Bergink, V., Laursen, T. M., Johannsen, B. M., et al.: Pre-eclampsia and first-onset postpartum psychiatric episodes: a Danish population-based cohort study. Psychol. Med., 2015, 45(16), 34813489 .

[51] Stramrood, C. A., Wessel, I., Doornbos, B., et al.: Posttraumatic stress disorder following preeclampsia and PPROM: a prospective study with 15 months follow-up. Reprod. Sci., 2011, 18(7), 645-653.

[52] Gaugler-Senden, I. P., Duivenvoorden, H. J., Filius, A., et al.: Maternal psychosocial outcome after early onset preeclampsia and preterm birth. J. Matern. Fetal Neonatal Med., 2012, 25(3), 272-276.

[53] Gadot, ., Koren, G.: The use of antidepressants in pregnancy: focus on maternal risks. J. Obstet. Gynaecol. Can., 2015, 37(1), $56-63$.

[54] Avalos, L. A., Chen, H., Li, D. K.: Antidepressant medication use, depression, and the risk of preeclampsia. CNS Spectr., 2015, 20(1), 39-47.

[55] Poel, Y. H., Swinkels, P., de Vries, J. I.: Psychological treatment of women with psychological complaints after pre-eclampsia. J. Psychosom. Obstet. Gynaecol., 2009, 30(1), 65-72.

[56] Mamelle, N. J., PPPB Study Group: Psychological prevention of early pre-term birth: a reliable benefit. Biol. Neonate, 2001, 79(3-4), 268-273.

(Szita Bernadett, Budapest, Baross u. 27., 1088 e-mail: szitabernadett@t-online.hu) 